\title{
Avla Dağ’da Yeni Dönem Tarihöncesi Araştırmaları: Ilk Gözlemler
}

\section{New Generation Prehistoric Investigations at Avla Dağ: Preliminary Observations}

\author{
Fevzi Volkan Güngördü1
}

${ }^{1}$ Nevşehir Hacı Bektaș Veli Üniversitesi, Fen Edebiyat Fakültesi, Arkeoloji Bölümü, Nevşehir, Türkiye

\section{ORCID ID: F.V.G. 0000-0002-8483-2415}

Sorumlu yazar/Corresponding author: Fevzi Volkan Güngördü,

Nevşehir Hacı Bektaş Veli Üniversitesi, Fen Edebiyat Fakültesi, Arkeoloji Bölümü, Nevşehir, Türkiye

E-mail: volkangungordu@nevsehir.edu.tr

Başvuru/Submitted: 10.11 .2021

Revizyon Talebi/Revision Requested: 28.11.2021 Son Revizyon/Last Revision Received:09.12.2021 Kabul/Accepted: 21.12.2021

Atıf/Citation: Gungordu, F.V., (2021). Avla Dağ'da yeni dönem tarihöncesi araștırmaları: Illk gözlemler. Anadolu Araştırmaları-Anatolian Research, 25, 1-25.

https://doi.org/10.26650/anar.2021.1021767

\section{öz}

Giorgio Pasquare tarafından 1963-1964yıllarında Maden TeknikArama Enstitüsü adına Nevşehir'de yapılan jeolojik yüzey araştırmaları sırasında, Avla Dağ'ın batı eteklerinde yoğun miktarda obsidiyenden üretilmiş yontmataş alet endüstrisine ait buluntular tespit edilmiştir. Aynı yıllarda Orta Anadolu Bölgesi'nde kapsamlı yüzey araştırmaları gerçekleştiren lan A. Todd, Avla Dağ tarihöncesi buluntularını incelemiş ve Giorgio Pasquare ve lan A.Todd'ın ortak çalışmasıyla Anatolian Studies dergisinde 1965 yılında "The Chipped Stone Industry of Avla Dağ" adlı bir makale yayınlanmıştır. Sonraki elli beş yıl boyunca Avla Dağ herhangi bir arkeolojik araştırmaya sahne olmamış ve tarihöncesi buluntuların erozyon sebebiyle toprak altında kaldığı varsayılmıștır. 2019 yılında NENESU (Nevşehir Neolitik Survey) projesi kapsamında Avla Dağ'da günümüz teknolojilerinin sağladığı avantajlar kullanılarak gerçekleştirilen arkeolojik yüzey araştırmaları, rüzgâr ve yağmur erozyonu sebebiyle gün geçtikçe daha fazla yok olma riski ile karşı karşıya kalan erken tarihöncesi buluntu yerlerinin tespit edilmesi vasıtasıyla Volkanik Kapadokya'nın erken tarihöncesi dönemlerinin anlamlandırılması sürecinde Merkezi Volkanik Kapadokya'nın yeri ve önemi üzerine yeni bilgilerin elde edilmesine olanak sağlamıştır. Bu makale, Avla Dağ'da 2019 yılında gerçekleştirilen yüzey araştırmaları üzerine ilk gözlemleri ortaya koymaktadır.

Anahtar Kelimeler: Kapadokya, Nevşehir, Avla Dağ, Tarihöncesi, Yontmataş, Çanak Çömlek

\section{ABSTRACT}

The geological surveys of Avla Dağ conducted by Giorgio Pasquare for the General Directorate of Mineral Research and Exploration (MTA) in 1963-1964 revealed dense traces of a lithic tool industry based on obsidian. Ian A. Todd, who comprehensively surveyed central Anatolia, analyzed the lithic material collected. Todd and Pasquare jointly published their results in Anatolian Studies in 1965, in a paper titled "The Chipped Stone Industry of Avla Dağ." In the subsequent 55 years, Avla Dağ was never investigated again archaeologically, and it was presumed that the prehistoric findings at Avla Dağ were covered with soil due to erosion. Avla Dağ was surveyed again in 2019 in the Nevşehir Neolithic Survey (NENESU) Project using modern technology. The results indicated central Volcanic Cappadocia's role in Cappadocian prehistory. This article aims to present the preliminary observations on prehistoric Avla Dağ based on the 2019 survey.

Keywords: Cappadocia, Nevşehir, Avla Dağ, Chipped stone, Pottery 


\section{EXTENDED ABSTRACT}

Geologically, "Volcanic Cappadocia" refers to the southeastern part of central Anatolia. This specific region is divided into three different areas based on the articulation of the volcanic geography. The first, the western part of the region known as western Volcanic Cappadocia, consists of the Hasan, Melendiz, Keçiboyduran, Göllü, and Nenezi mountains and the volcanic geography around them. The Melendiz River is the main water source for this area. The second area, central Volcanic Cappadocia, mainly refers to Nevşehir city and its peripheral area comprising the volcanic domes around the Ac1göl and Derinkuyu areas. However, volcanic landforms spread out to the whole city. The Kizılırmak River, which flows in the east-west direction in Nevşehir, is the main water source for central Volcanic Cappadocia. Aside from the volcanic activities, the Kizılırmak River creates different valleys and unique landforms. The Erciyes mountain and the volcanic geography around it form the eastern part of Volcanic Cappadocia, the third area in the region.

The prehistoric archaeology of Volcanic Cappadocia is based mainly on research conducted by İstanbul University's department of prehistoric archaeology. However, all of these projects focused on the western part of the region and produced limited data for the other areas of Volcanic Cappadocia.

The only available data on the prehistoric archaeology of central Volcanic Cappadocia come from survey projects carried out in the 1960s and the 1990s. With the exception of Ian Todd's surveys in the 1960s, these projects focused on specific parts of the region without a holistic perspective, thus reducing the role of this central area in the prehistory of Volcanic Cappadocia. The Nevşehir Neolithic Survey (NENESU) started with the specific aim of obtaining an integrated view of the role of central Volcanic Cappadocia in both Cappadocian and Central Anatolian prehistory.

The first season of the NENESU survey explored the southeastern part of Nevşehir city, mainly the Ürgüp area. Avla Dağ is located $8 \mathrm{~km}$ southeast of Ürgüp on the eastern side of the Damsa River, which is a tributary of the Kizllırmak River. The geological surveys on Avla Dağ that were conducted by Giorgio Pasquare for the General Directorate of Mineral Research and Exploration (MTA) in 1963-1964 yielded many obsidian materials and some pottery fragments. Ian A. Todd analyzed the lithic material from this survey and published his results jointly with Pasquare in Anatolian Studies in 1965, in an article entitled "The Chipped Stone Industry of Avla Dağ." Throughout the 55 years subsequent to the publication, there was no new research on this site, leading to the presumption that the prehistoric findings at Avla Dağ became invisible due to soil erosion. The main aim of the NENESU survey in 2019 was the determination of the prehistoric locations in Avla Dağ by means of modern technology, geographical information systems (GIS), and 3D modeling of the site. 
This 2019 survey led to the rediscovery of six different locations that Todd and Pasquare defined. This article summarizes the survey methodology, the exploration of the locations, and the geographical characteristics of the prehistoric locations and discusses Avla Dağ from a holistic perspective. Lastly, the paper discusses the preliminary observations on the archaeological materials found in Avla Dağ. 


\section{Giriş}

Orta Anadolu Bölgesi’nin güneydoğusu volkanizma temelli yeryüzü şekillerinin yoğunluğu nedeniyle jeologlar tarafından "Volkanik Kapadokya" olarak adlandırılmıştır (Toprak, 1998: 55). Kuzeyde Orta Kızılırmak bölgesinin, güneyde Toros Dağları'nın, doğuda Tecer Dağları'nın ve batıda Konya Ovası'nın sınırladığı bölge, farklı coğrafi özellikler gösteren birçok ekolojik nişi içerisinde barındırmaktadır (Duru 2018: 160). Volkanizmanın coğrafi yayılımı göz önünde bulundurulduğunda bölge üç farklı bölüm içerisinde değerlendirilebilir. Volkanik yeryüzü şekillerinin yoğun olarak görüldüğü "Batı Volkanik Kapadokya", günümüzde Aksaray ve Niğde illerini kapsayan alan ile ifade edilmektedir. Hasan Dağ, Melendiz Dağ, Keçiboyduran Dağ, Göllü Dağ ve Nenezi Dağ, bölge volkanizmasının ana karakterleri olarak tanımlanabilir. Nevşehir ili ve çevresi kapsamında değerlendirilen "Merkezi Volkanik Kapadokya" bölgesinin oluşumunda Acıgöl ve Derinkuyu çevresindeki zengin volkanik çeşitlilik etkili olmuştur. Erciyes Dağ ve çevresi çerçevesinde tanımlayabileceğimiz "Doğu Volkanik Kapadokya" bölgesi ise günümüzde Kayseri ili ve çevresi ile ifade edilmektedir (Resim 1).

Volkanik Kapadokya Bölgesi’nde günümüzde karasal iklim ve buna bağlı olarak bozkır bitki örtüsü yaygın olarak görülmektedir. Yıllık yağış miktarının 300-330 mm civarında olduğu bölge kuru tarım için uygun olanakları sağlamaktadır. Akgöl ve Acıgöl polen analizlerinin ortaya koyduğu sonuçlar 1şı̆̆ında, Kapadokya'da tarihöncesi dönemler içerisinde yaşanan iklimsel değişimler gözlemlenebilmektedir. Eldeki veriler doğrultusunda Son Buzul Maksimum döneminde bölgede kurak, bozkır bitki örtüsünün hâkim olduğu görülmektedir. Bolling-Allerød döneminde sıcaklık ve nem oranlarında yaşanan yükselmenin bir sonucu olarak hem meşe ormanlarının hem de buğdaygillerin yaygınlaştıkları tespit edilmiştir. Ancak Younger Dryas ile birlikte, Neolitik Çă̆’ın başlangıcının hemen öncesinde, soğuk ve kurak iklim koşullarının bölgeye tekrar hâkim olduğu gözlemlenmektedir. Holosen döneminin başlangıcında sıcaklık ve nem oranlarının yükseldiği gözlemlenmiştir. Acıgöl verileri MÖ. 12.000 civarında yaz sıcaklıkların günümüz seviyesinde olduğunu, yağış oranlarının ise günümüzden \%40 oranında yüksek olduğuna işaret etmektedir. Nar Gölü verileri ise Kapadokya'da yağış oranlarının kademeli bir biçimde MÖ. 4000 yıllarına kadar artış gösterdiğini ortaya koymaktadır (Roberts 2014: 70-81, Kuzucuoğlu, Roberts 1997: 1718, Kuzucuoğlu 2002: 37).

Volkanik Kapadokya Bölgesi'de rüzgâr ve yağmur aşındırmasının güçlü izleri net bir şekilde izlenebilmektedir. Bölge ile özdeşleşmiş, bölgenin simgesi olarak ta tanımlayabileceğimiz "peribacaları"nın oluşumunda da bu iki faktörün neden olduğu aşındırma, temel sebep olarak gösterilebilir. Rüzgâr ve yağmurun coğrafya üzerinde neden olduğu sürekli değişism, arkeolojik buluntu alanlarının tespiti açısından önemli zorlukların ortaya çıkmasına neden olmaktadır. Bahsedilen bu hareketliliğin bir sonucu olarak, birçok 
arkeolojik alanda buluntular, orijinal konumlarından uzaklaşır ve üzerlerini kaplayan toprak dolguları sebebiyle tespit edilebilirlikleri güçleşmektedir. Bu araştırmanın sorunsalı olan Avla Dağ üzerindeki tarihöncesi buluntu yerlerinin tespiti de, yukarıda bahsedilen sebeplerden dolayı her geçen gün çok daha güç bir hale gelmektedir.

Merkezi Volkanik Kapadokya bölgesi sınırları içerisinde bulunan Avla Dağ, Nevşehir il merkezinin 20 km doğusunda, Ürgüp ilçesinin 8 km güneydoğusunda, Damsa Çayı'nın aktığ1 vadinin doğu kenarında konumlanmıştır (Resim 2-4). Kuzey-güney doğrultusunda 16 km lik bir uzunluğa sahip olan dağ, en geniş bölümünde, doğu-batı yönünde $4.5 \mathrm{~km}$ lik bir alanı kaplamaktadır (Resim 2-3).

Kızılırmak Nehri'nin bir kolu olan Damsa Çayı, Ürgüp ilçesi ve çevresi için temel su kaynağ1 olarak tanımlanabilir. Kuzey-güney doğrultusunda akış gösteren çay, doğu ve batısında oluşturduğu kollarıyla beraber, batıda Mustafapaşa, Cemil, Taşkınpaşa, Şahinefendi mevkileri ile doğuda Avla Dağ eteklerindeki muhtemel yerleşim alanları için su kaynakları açısından büyük öneme sahiptir. Damsa Çayı'nın oluşturduğu vadinin deniz seviyesinden yüksekliği 500 m civarındadır. Ortalama yükseltinin 900 m olduğu Volkanik Kapadokya bölgesinde, özellikle soğuk iklim koşullarının yaşandığı dönemlerde Damsa vadisi mevsimlik yerleşim stratejisini benimsemiş insan toplulukları için korunaklı bir alan oluşturması sebebiyle son derece önemlidir.

Avla Dağ'da ilk bilimsel araştırmalar 1963-1964 yıllarında Giorgio Pasquare tarafından gerçekleştirilen jeolojik yüzey araştırmalarıdır. Pasquare, Avla Dağ’’ karasal, nehirsel ve göl depositlerinin karıştığı bir volkanik tüf tabakası olarak tanımlar ve oluşumunda MiyosenPaleosen dönemleri arasındaki bir zaman dilimi içerisinde Erciyes Dağ'ında gerçekleşen volkanik patlamaların etkili olduğunu belirtir. Çok düzgün bir doğrultuda yatay pozisyonda konumlanan bu volkanik tüf tabakasının zirve kısmında ise ignimbritik bir tüf formasyonu bulunmaktadir (Todd, Pasquare 1965: 95).

Pasquare'in Avla Dağ'da gerçekleştirdiği jeolojik yüzey araştırmaları esnasında, dikkat çekici miktarda obsidiyen buluntuların tespit edilmesi üzerine, alan daha sonra Ian Todd tarafından tekrar ziyaret edilir ve 1965 yılında Anatolian Studies dergisinde ortak bir çalışma yayınlanır.

Todd ve Pasquare, Avla Dağ'ın, Damsa Nehri'nin aktığı vadiye bakan batı yamacında, altı farklı konumda, obsidiyen buluntuların varlığından bahsetmektedir. Özellikle batı yamacının alçak seviyelerinde kuzeyden güneye doğru 1,5 ve 2 numaraları ile adlandırılan alanlarda tespit edilen buluntuların nitelik ve nicelik açısından yoğunluğu dikkat çekicidir ve bu sebeple Avla Dağ endüstrisinin merkezi olarak tanımlanmışlardır. Daha yüksek seviyelerdeki 3, 6 ve 4 numaralı alanlar da saptanan buluntular ise sayısal olarak çok daha 
azdır (Resim 3). Bu azlığg Todd ve Pasquare dağın yüksek kesimlerine ulaşımın zor olması ile ilişkilendirmişlerdir (Todd, Pasquare 1965: 97).

\section{Nevşehir'de Tarihöncesi Araştırmaları}

Nevşehir ili sınırları içerisinde, bölgenin tarihöncesi dönemlerine dair araştırmalar göz önünde bulundurulduğunda en erken çalışmaların 1960'lı yıllarda gerçekleştirildiği görülmektedir. Giorgio Pasquare 1963 ve 1964 yıllarında, Ürgüp ilçesi sınırları içerisinde bulunan Avla Dağ'da jeolojik yüzey araştırmaları gerçekleştirmiştir (Todd, Pasquare 1965: 95). 1964 ve 1966 yıllarında Ian Todd'un Orta Anadolu Bölgesi' de yaptığı yüzey araştırmaları kapsamında, Nevşehir sınırları içerisindeki farklı alanlar incelenmiştir (Todd 1980, Özbaşaran 2011: 103). 1990'larda Sachirio Omura, Nur Balkan-Atlı ve Marie Claire Cauvin, Süleyman Yücel Şenyurt ve Sevil Gülçur'un Nevşehir'in farklı bölgelerinde gerçekleştirdikleri yüzey araştırması projeleri bölgenin tarihöncesi buluntu yerlerinin anlaşılması noktasında önemli bilgiler ortaya koymuşlardır (Omura 1990, Şenyurt 1998, 1999, Balkan-Atlı ve Cauvin 1998, Gülçur, 1999). 2011 yılında Okşan Başoğlu’nun Ürgüp ilçesinde yaptığı paleoantolojik yüzey araştırmaları sırasında saptanan Sofular Höyük’te 2016 yılında arkeolojik kazılar başlatılmış ve Çanak Çömleksiz Neolitik Dönem’e tarihlenen buluntular açığa çıkartılmıştır (Güngördü, Başoğlu 2019).

Bölgesel ölçekte yapılan çalışmalar, özellikle Nevşehir ili ve ilçelerinin tümü göz önünde bulundurulduğunda, güncel araştırmaların gerekliliğini açıkça ortaya koymaktadır. Bu gereklilik doğrultusunda "Nevşehir ili Neolitik Çağ Yüzey Araştırmaları" (NENESU) projesi $^{1}, 2019$ yılında bölgede araştırmalarına başlamıştır.

\section{Yöntem}

Nenesu projesi 2019 yılı çalışmalarının odak noktası, Avla Dağ'da 1960'lı yıllarda Todd ve Pasquare'in araştırmalarıyla bilim dünyasına duyurulan, ancak günümüzde büyük ölçüde rüzgâr ve yağmur nedenli yoğun erozyon sebebiyle tespit edilebilirliğini yitirdiği düşünülen, tarihöncesi dönemlere ait yaşam izlerinin, güncel teknolojiler kullanılarak tekrar saptanmasıdir.

Todd ve Pasquare'in Avla Dağ'ın yontma taş endüstrisi üzerine hazırladıkları, 1965 yılında Anatolian Studies dergisinde yayınlanan makalede, saptanan buluntu yerlerini gösteren harita, "QGIS" yazılımı kullanılarak, güncel Google Earth haritası üzerine aplike edilerek, buluntu yerlerinin konumları belirlenmeye çalışılmıştır². Google Earth vasıtasıyla,

1 Nevşehir Hacı Bektaş Veli Üniversitesi, Arkeoloji Bölümü hocaları ve öğrencilerinden oluşan bir ekip çerçevesinde.

2 Bu süreçte Yalçın Kamış'a destekleri için teşekkür ederiz. 
belirlenen konumlardan elde edilen "KML" " ve "KMZ4" konum dosyaları, mobil GPS programlarına gönderilmiştir. Günümüz navigasyon yazılımları ile entegre çalışan mobil GPS programları sayesinde Todd ve Pasquare'in saptadığ uygun rotalar saptanmıştır.

Tespit edilen lokasyonlara, zorlu arazi koşulları sebebiyle yaşanan erişim zorluğu, arazi aracı vasıtasıyla çözülmeye çalışılmıştır. Ancak saptanan bazı konumların sert topografik karakterleri sebebiyle, belirlenen konumlara ulaşım, çoğu zaman yürüyerek gerçekleşmiştir. Arazi ekibi, saptanan konumlara ulaştığında, her ne kadar mobil GPS yazılımlarının yönlendirdikleri konum bilgileri temel alınsa da bu konumların içinde bulundukları daha geniş alanlar da ekip üyeleri tarafından taranmıştır. Ekip üyelerinin oluşturdukları hattın başında ve sonunda konumlanan bireyler "Compass 55" adlı yazılım vasitasıyla, taranan hattın her iki ucundan rota kaydı tutmuşlardır. Bu sayede günlük taranan alanlar "GIS" ortamında izlenebilir hale getirilmiştir. Tarama esnasında bir konumda buluntu yoğunluğu tespit edildiğinde ise, “Compass 55" yazılımında ayrı bir kayıt girdisi açılmış ve ekibin diğer üyeleri alanın iç kısmını araştırırken, yazılım kullanan iki kişi arkeolojik malzemenin yayılımının sınırlarını belirlemiştir. Alanda saptanan her bir buluntu için konum bilgisi yine nokta alım yöntemiyle "Compass 55" yazılımı vasıtasıyla üretilmiştir.

Günlük arazi çalışması tamamlanmasıyla birlikte, alınan rota kayıtları, alan sınır bilgileri ve buluntu konum bilgileri, elektronik ortama aktarılmıştır. "ALOS Research and Application Project" ve "US Geological Survey" projelerinin internet sayfalarından sağlanan dijital yükseklik modelleri, "DEM", vasıtasıyla "GIS" ortamında oluşturulan haritalar üzerine, günlük arazi çalışmaları sonrasında elde edilen veriler işlenmiştir.

Buluntu yoğunluğu açısından dikkat çeken konumlardan elde edilen veriler 1şığında tespit edilen alanların üç boyutlu modeli "Agisoft" yazılımı kullanılarak hazırlanmış ve bu model vasıtasıyla üretilen "geotiff” formatlı resim dosyası, "QGIS” yazılımına yüklenmiştir. Buluntu dağılım verileri aynı dosya üzerine eklenerek, üç boyutlu model üzerinde arkeolojik buluntuların dağılımı gözlemlenmiştir.

Yukarıda bahsedilen belgeleme metodolojisi özellikle rüzgâr ve yağmur nedeniyle yaşanan yoğun erezyonun etkilerinin açıkça görüldüğü ve arkeolojik buluntuların bu sebeple yer değiştirdiği alanlarda, hem yeni araştırmacılara hem de buluntu yerlerinin aynı kişilerce tekrar ziyaret edilmesi sürecine büyük kolaylıklar sağlamaktadır.

3 Keyhole Markup Language

4 Keyhole Markup Language Zipped 


\section{Avla Dağ Tarihöncesi Buluntu Yerleri}

\section{Avla Dă̆ 2}

Avla Dağ 2 buluntu yeri, Damsa Baraj Gölü’nün kuzeyinde, Tortuman Deresi'nin doğusunda, Cemece Deresi'nin güneyinde konumlanmaktadır. Avla Dağ'ın alçak yamaçlarında konumlanmış olan buluntu yerinde arazi engebelidir. Bazı alanlarda iri boyutlu bazalt taşları görülmektedir. Peribacası oluşumlarının dikkat çektiği bölgede yabanıl bitki örtüsü egemendir (Resim 5).

Todd ve Pasquare'in Teras 2 olarak tanımladığı bu alanda gerçekleştirdikleri yüzey araştırmaları sonucunda iki yüzeyli düzeltili bir okucu parçası saptanmıştır. Ayrıca üçgen ya da trapezoid kesitli tek yüzeyinde düzeltiler bulunan dilgi örneklerinin yoğunluğu vurgulanmaktadır (Todd, Pasquare 1965: 98).

2019 yılı araştırmaları sonucunda 5.5 hektarlık bir alanda, dağınık vaziyette obsidiyen ve daha az sayıda çakmaktaşı buluntular tespit edilmiştir. Yonga üzeri alet olarak tanımlanabilecek obsidiyen ve çakmaktaşı kazıyıcı örneklerinin görüldüğü alanda, baskı tekniğiyle üretilmiş dilgi parçası örnekleri de saptanmıştır (Tablo 1, Resim 6). Baskı tekniğinin dilgi üretim sürecinde tercih edilmesi, Neolitik ve Kalkolitik Çağlar için yaygın bir uygulamadır. Ayrıca alanda saptanan bir çakmaktaşı yonga üzerindeki kullanım izleri alanın Paleolitik Çağlarda da insan toplulukları tarafından ziyaret edildiğini düşündürmektedir.

\section{Avla Dağ 5}

Avla Dağ 5 buluntu yeri, Avla Dağ 2 buluntu yerinin kuzeyinde, Kurt Deresi'nin doğusunda ve Cemece Deresinin kuzeyinde konumlanmaktadır. Damsa Çayı vadisine bakan yamacın hemen bitiminde 1 hektarlık bir alan içerisinde kuzey-güney doğrultusunda $50 \mathrm{~m}$ uzunluğunda ve doğu batı doğrultusunda $5 \mathrm{~m}$ lik bir küçük tepeciktir; bu tepeciğin etrafinda yoğun obsidiyen malzeme tespit edilmiştir (Resim 7-8).

Todd ve Pasquare Teras 5 olarak adlandırdıkları alanda çok sayıda obsidiyen dilgi parçası örneğinden bahsetmektedir. Tek yüzeyli düzeltili, üçgen ya da trapezoid kesitli örnekler göze çarpmaktadır. Obsidiyenden üretilmiş disk biçimli, kenarlarında düzeltiler bulunan kazıyıcı örneklerininde görüldüğü alanda bazalttan üretilmiş bir Aşölyen el baltası örneği, alanın Alt Paleolitik Dönem'de de kullanıldığını ortaya koymaktadır (Todd, Pasquare 1965: 98, 105, $108,112)$.

Alanda 2019 yılında gerçekleştirilen araştırmalar sonucunda, çok sayıda üretim artığının yanı sıra yonga parçası örnekleri ve baskı tekniği ile üretilmiş bazı dilgi parçası örnekleri tespit edilmiştir (Tablo 1, Resim 6, 4-5, Çizim 1). Ayrıca tarihöncesi dönemler içerisinde değerlendirebileceğimiz el yapımı, mineral ve bitkisel katkılı, özlü, kahverengi astarlı, bazı 
örneklerde alacalı, dış yüzeyleri açkılı iç yüzeylerinde ise ince düzeltmelerin olduğu bir çanak çömlek grubu da görülmüştür (Resim 9-10). Hem çanak çömlek örnekleri hem de bask1 tekniğinde üretilmiş dilgi parçası örnekleri alanın Neolitik-Kalkolitik Çağlar kapsamında insan toplulukları tarafindan kullanıldığına işaret etmektedir.

\section{Avla Dă̆ 4}

Avla Dağ 4 buluntu yeri, Avla 2 ve 5 buluntu yerleri ile karşılaştırıldığında daha doğuda, Avla Dağ’’ın daha yüksek seviyelerinde, Cemece Deresi'nin doğusunda konumlanmaktadır. Toplam 9 hektarlık bir alan taranmış ve kuzey-güney doğrultusunda uzanan bir vadinin doğu yamacında, 0.5 hektarlık bir alanda bir buluntu yoğunluğu tespit edilmiştir. Obsidiyen ve daha az sayıda çakmaktaşından üretilmiş buluntular arasında dilgi üzeri aletler ve yonga üzeri aletler görülmüştür (Tablo 1). Ayrıca obsidiyenden üretilmiş iki yüzeyli düzeltili bir okucu örneği saptanmıştır (Resim 6, 1). Karşılaştırılabilecek benzer bir örnek Todd ve Pasquare'in araştırmalarında Teras 2 olarak tanımlanan alandan bilinmektedir (Todd, Pasquare 1965: 98). İki yüzeyli düzeltiye sahip okuçları Volkanik Kapadokya Bölgesi'nde İlk Neolitik, Son Neolitik ve Kalkolitik Çağ yerleşimlerinden bilinmektedir (Öztan 2021: 69, Balc1 2019: 237 , 240, Kayacan 2018: 49-50, 58).

\section{Avla Dağ 6}

Avla Dağ 6 lokasyonu Kurt Deresi'nin doğusunda, Avla 4 lokasyonun kuzeyinde ve Avla 5 lokasyonunu doğusunda konumlanmıştır. 1300 m yükseklikte dağın zirve kısmının yakınlarındadır. Bu alanda gerçekleştirilen çalışmalarda doğu-batı doğrultusunda 1 hektarlık bir alanda az sayıda düzeltili dilgi ve yonga üzeri alet örnekleri saptanmıştır (Tablo 1).

\section{Avla Dă 1 ve 3}

Avla Dağ 1 ve 3 buluntu yerleri, Avla Dağ'ın diğer buluntu yerleri ile karşılaştırıldığında çok daha kuzeyde olmaları ile dikkat çekmektedir. Avla Dağ 1 buluntu yeri Çamurluklukol Deresi ile Velioğlusöğütler derelerinin arasında doğuya, dağın zirvesine doğru uzanan bir alandır. Farklı vadi boyları tarafından doğu-batı doğrultusunda bölünen alanda toplam 26 hektarlık bir bölge taransa da az sayıda obsidiyen yonga parçası dışında herhangi bir buluntu ile karşılaşılmamıştır (Tablo 1). Alanda Todd ve Pasquare'in gerçekleştirdiği araştırmalarda ise çok sayıda obsidiyen dilgi parçası örneğinin yanı sıra okucu ve delici örnekleride gözlemlenmiştir (Todd, Pasquare 1965: 98-100, 109).

Avla Dağ 3 buluntu yeri Avla Dağ 1 buluntu yerinin doğusunda Avla Dağ'ın zirvesine doğru, Kale Tepesi ile Karabucak Tepesi'nin arasındadır. 1400 m yükseklikteki alanda yamaç boyunca kuzey-güney doğrultusunda 3 hektarlık bir alan taranmış, ancak az sayıda obsidiyen yonga parçası saptanmıştır (Tablo 1). 
Todd ve Pasquare'in 1960'lı yıllarda gerçekleştirdikleri araştırmalar ile NENESU projesi kapsamında 2019 yılında Avla Dağ’ın batı terasında yapılan çalışmalar değerlendirildiğinde bazı benzerlikler ve farklılıklar göze çarpmaktadır. Her iki araştırmanında vurguladığı üzere Avla Dağ'ın Damsa Çayı vadisine bakan batı yamacının alçak terasları, buluntu yoğunluğu açısından daha yüksek seviyedeki alanlara nazaran çok daha çeşitlidir. 2019 yılı çalışmaları özellikle Avla Dağ 2 ve 5 numaralı buluntu yerlerinin diğer alanlarla karşılaştırıldığında nitelik ve nicelik açısından daha zengin olduğunu göstermektedir. Ancak Todd ve Pasquare'in çalışmalarının aksine Avla Dağ 1 alanında tespit edilen buluntu sayısı son derece düşüktür. 2019 yılı çalışmalarında alet olarak tanımlanabilecek örnekler çoğunlukla dilgi parçaları, dilgi üzeri aletler ve yonga üzeri aletler olarak tanımlanabilir (Tablo 1). Avla Dağ 4 buluntu yerinde tespit edilen baskı düzeltili okucu örneği 1960'lı yılların örnekleri ile karşılaştırılabilecek niteliktedir.

\section{Tartıșma}

Volkanik Kapadokya Bölgesi'nin merkezi olarak tanımlayabileceğimiz Nevşehir ili ve çevresi göz önünde bulundurulduğunda, bölgenin en önemli su kaynağı olan Kızılırmak Nehri’nin ana akış doğrultusu, Ürgüp'ün kuzeyinde, Avanos-Gülşehir hattı boyunca doğubatı yönündedir. Ürgüp ilçesi ve çevresine bakıldığında ise Kızılırmak Nehri’nin farklı kolları, bölgede kuzey-güney doğrultusunda akış göstermektedirler. Avla Dağ'ın batı yamacının kenarında, aynı doğrultuda akan Damsa Çayı, Ürgüp ve çevresi için temel su kaynağı olarak değerlendirilebilir.

Kuzey-güney doğrultusunda akan Damsa Çayı'nın oluşturduğu vadinin doğusu ve batısı topografik açıdan değerlendirildiğinde, yükseltinin değişimi noktasında farklı karakterler ortaya koymaktadırlar. Vadinin batısında kademeli bir biçimde yükselti seviyelerinin artış1 gözlemlenirken, vadinin doğusunda açıkça fark edilebilen ani yükselti değişimiyle Avla Dağ, kuzey-güney yönünde adeta bir sur duvarı görünümünü kazanmıştır. Bu nedenle Damsa Çayı vadisinin batısında su kaynağının etkin bir şekilde gözlemlenme olanağı, sadece vadiden gittikçe uzaklaşıldığı zaman sağlanmaktadır. Ancak bu durumda su kaynağı ve aktığg vadinin izlenebilirlik oranı son derece düşüktür. Buna karşılık tam tersine yukarıda da belirtildiği üzere vadinin doğusunda adeta bir sur duvarı şeklinde uzanan Avla Dağ'ın batı yamacı, ortaya koyduğu ani yükselti farkı sebebiyle, çok fazla mesafe kat etmeden vadinin kontrolüne olanak sağlaması avantajı doğrultusunda bölge için bir hâkimiyet alanı olarak tanımlanabilir.

Pleistosen ve Erken Holosen dönemleri boyunca insanoğlunun temel besin elde etme stratejisinin büyük ölçüde avcılık ve toplayıcılığa dayandığı bilinmektedir. Bu dönemler kapsamında, Ürgüp bölgesinin ana su kaynağı olarak tanımlayabileceğimiz Damsa Çayı'nın aktığı vadiye hâkim konumuyla Avla Dağ, bölgenin tarihöncesi sakinlerinin besin elde etme stratejileri açısından ayrı bir öneme sahiptir. Avla Dağ batı yamacı, sağladığı bu hâkimiyet 
avantajı ile hem hayvan sürülerinin gözlenmesi hem de avcı grupların bu sürüler tarafından fark edilemeyecek (Resim 11) bir uzaklıkta olmaları sebebiyle, avcılık faaliyetleri açısından stratejik bir öneme de sahiptir. Bunun yanı sıra batı yamacının içinde barındırdığı su kaynakları da benzer bir şekilde özellikle yükseklik açısından daha üst seviyelerde yaşamaya uyum sağlamış olan hayvan türleri için önemli bir çekim bölgesidir. Batı yamaç, daha küçük ancak yerleşime uygun başka mikro alanları da içerisinde barındırmaktadır. Örneğin Tortuman Deresi'nin aktığı vadi alanı, yeşil bitki örtüsü ve volkanik kaya oluşumlarıyla dikkat çekmektedir. Bu mikro bölgenin merkezinde bulunan açık alanın etrafını çeviren kayalık, bir nevi koruyucu duvar fonksiyonu görmektedir. Tortuman Deresi bu açık alanın kenarından akmaktadır. Alan, korunaklılığının yanı sıra su kaynağına da sahip olması sebebiyle tarihöncesi insan topluluklarının yerleşim stratejileri açısından uygun koşulları sağlamaktadır (Resim 12). Avla Dağ 5 buluntu yeri için de benzer şartlardan söz edilebilir. Damsa Çayı vadisine hâkim konumu hayvan sürülerinin hareketlerinin fark edilmeden izlenebilmesine olanak sağlamaktadır. Ek olarak kuzeybatısında bulunan Kurt Deresi ve güneydoğusunda bulunan Cemece Deresi'ne yakın konumu da su kaynaklarına yakınlık açısından avantajlıdır. Dolayısıyla Avla Dağ 2 ve 5 buluntu yerleri hem tarihöncesi topluluklarının su ihtiyaçlarını sağlarken, aynı zamanda bu su kaynaklarının av hayvanlarını da bölgeye çekmeleri sebebiyle avcılık faaliyetleri açısından uygun alanlar olarak tanımlanabilirler.

Avla Dağ, iklimsel koşullara bağlı olarak değişkenlik gösteren bir av, konaklama ya da yerleşim stratejisi için uygun çevre koşullarını sağlamaktadır. Sıcaklık derecelerinin yüksek seviyelere ulaştığı yaz aylarında, Damsa Çayı vadisinin sıcaklık ve neme bağlı olarak daha elverişsiz bir ortam sağlaması, aksine Avla Dağ yamaçlarının yükselti sebebiyle sıcaklık değerleri açısından daha uygun bir yaşam alanı oluşturması ve yamaçta bulunan farklı su kaynakları, mevsimlik bir yerleşim stratejisi için uygun koşulları sağlamaktadır. Sıcaklık değerlerinin daha düşük seviyelere ulaştığı kış aylarında ise Damsa Çayı vadisi alçak konumu ve vadinin korunaklı yapısı sayesinde mevsime uygun çevre şartlarını sunmaktadır.

Damsa Çayı vadisi ve Avla Dağ’ın batı yamacının oluşturduğu özel bölge (Resim 2), topografya, iklim, bitki örtüsü ve farklı dönemleri içeren buluntu yerlerini içerisinde barındırması sebebiyle Azraq Havzası ile benzerlikler göstermektedir. Ürdün'ün kuzeydoğusunda konumlanan Azraq Havzası $12.000 \mathrm{~km}^{2}$ lik bir geniş direnaj alanıdır. Havza, günümüzde yarı kurak-kurak, bozkır ve çöl bitki örtüsünün hâkim olduğu birçok vadi ve mevsimsel bataklık alanını içerisinde barındırmaktadır (Richter v.d., 2013: 467-468). Azraq Havzası'nda 1975-1988 yılları arasında altı sezon, havzanın Geç Pleistosen-Erken Holosen dönemleri içerisinde geçirmiş olduğu çevresel değişimlerin ve bunun sonucu olarak yerleşim ve geçim stratejilerinin nasıl değiştiğinin anlaşılması amacıyla El-Jilat, El Uwaynid ve merkezi havza olarak tanımlanan üç farklı alanda araştırmalar gerçekleştirilmiştir. (Garrard v.d., 1988:40, Byrd 1988: 257). 
El-Jilat vadisi $160 \mathrm{~km}^{2}$ lik bir alanı kaplamaktadır. Vadinin ortalama deniz seviyesinden yüksekliği 967-755 m arasındadır. Çakmaktaşı ve kireçtaşı yataklarının bulunduğu vadinin özellikle alçak kesimleri su kaynakları açısından önemli bir potansiyele sahiptir (Garrad v.d., 1988: 40). Azraq havzası sınırları içerisinde bulunan el-Uwaynid vadisi, Azraq'ın 10 km güneybatısında konumlanan $10 \mathrm{~km}$ uzunluğundaki Jebel Uwaynid bazalt uzantısının yakınında konumlanmaktadır. Vadi merkezi, bir bataklık alanın ve çevresindeki göl depositlerinden oluşmaktadır (Byrd 1998: 42, Garrard v.d., 1998: 42). Araştırmaların üçüncü ana bölgesini oluşturan merkezi havza ise göl ve bataklık alanlarının bulunduğu su kaynakları açısından zengin bir bölge olarak tanımlanabilir (Garrard v.d., 1998: 44).

Azraq Havzası'nda 1975-1988 yılları arasında sistemli araştırma çalışmaları gerçekleştirilmiştir. 1975 ve 1982 yıllarını kapsayan ilk dönemde, küçük ölçekli yüzey araştırmaları yapılmış, 1984 ve 1985 yıllarında saptanan Üst Paleolitik, Epi-Paleolitik ve Neolitik Çağ buluntu yerlerinde sondaj çalışmaları yapılmıştır. 1987-1988 yıllarında dört farklı Neolitik yerleşiminde arkeolojik kazı çalışmaları gerçekleştirilmiştir. Bozkır coğrafyasının hâkim olduğu Azraq Havzası'nda bulunan vadilerde yılın belli dönemlerinde iklim ve dolayısıyla yağışa bağlı olarak su kaynaklarının kullanılabilir olduğu görülmektedir. Eldeki veriler hem yabanıl hem de kültüre alınmış bitkisel ve evcil hayvansal kaynaklarının havza sakinleri tarafından tüketildiğini ortaya koymaktadır. Açığa çıkartılan mimari buluntuların oval ya da daire planlı, toprağa gömük, üst yapı öğelerinin ise organik materyallerden üretildikleri görülmektedir. Tespit edilen yapı örneklerinin geçici özellikleri sürekliliğin aksine mevsimsel bir yerleşim stratejisinin Azraq Havzası Neolitik Çağ toplulukları tarafından benimsendiğini ortaya koymaktadır. Sürtmetaş endüstrisi içinde tanımlayabileceğimiz taşınabilir havaneli ve ezgi taşı örnekleri de bu görüşü destekler niteliktedir (Garrard, vd., 1994: 106-107. Garrard v.d., 1998: 40).

Azraq Havzası, içerisinde barındırdığı vadileri, zengin su kaynakları, iklim ve bitki örtüsü açısından değerlendirildiğinde Avla Dağ ve Damsa çayı vadisinin oluşturduğu özel bölge ile benzer nitelikler ortaya koymaktadır. Ayrıca havzada saptanan Üst Paleolitik, EpiPaleolitik ve Neolitik Çağ'a tarihlendirilen buluntu yerlerinin ortaya koyduğu uzun dönemli yerleşim karakteri, Avla Dağ buluntuları üzerinden değerlendirildiğinde bölge için beklenen bir durumdur.

\section{Sonuç}

1963-1964 yılları arasında Pasquare ve Todd'un gerçekleştirdiği araştırmalardan sonraki elli beş yıllık zaman aralığı içerisinde Avla Dağ, bilimsel araştırmalardan yoksun kalmıştır. Bölgenin iklim koşullarının neden olduğu yoğun erozyona sürekli maruz kalması özellikle erken tarihöncesi buluntu yerlerinin tespit edilmesini gün geçtikçe zorlaştırmaktadır. 2019 yılında "Nenesu" projesi kapsamında Avla Dağ üzerinde gerçekleştirilen ilk "yeni dönem" 
araştırmaları gün geçtikçe yok olmaya yüz tutan hem Orta Anadolu bölgesi hem de Volkanik Kapadokya açısından son derece önemli bir alandaki buluntu yerlerinin tespit edilmesi açısından son derece önemlidir.

Avla Dağ'da 2019 yılı yüzey araştırmalarında saptanan yontmataş alet endüstrisine ait örneklerin büyük bir bölümü obsidiyenden üretilmiştir. Çakmaktaşı buluntular ise çok az sayıdaki örnekle temsil edilmektedirler. Buluntuların yoğunluğu açısından Avla Dağ’ın alçak teraslarında konumlanmış olan 2 ve 5 numaralı merkezler, dikkat çekmektedirler. Buluntular baskı tekniğinde, paralel düzeltili üçgen ya da trapez kesitli dilgi parçaları, dilgi üzeri aletler ve yonga üzeri aletlerin yanı sıra minik atık olarak tanımlanabilecek parçalardan oluşmaktadır (Tablo 1). Paralel düzeltili baskı dilgi parçaları Neolitik ve Kalkolitik Çăg' da bölgeden bilinmektedir. Avla Dağ 4 buluntu yerinde saptanan ve her iki yüzeyinde bask1 düzeltinin bulunduğu bir obsidiyen okucuna benzer örnekler, Köşk Höyük ve TepecikÇiftlik yerleşimlerinden bilinmektedir. Köşk Höyük’te Çanak Çömlekli Neolitik Dönem'e tarihlendirilen III. tabakada benzer bir örnek tespit edilmiştir (Öztan 2021: 69). TepecikÇiftlik yerleşiminde ise Çanak Çömlekli Neolitik Dönem tabakalarında oval ya da yaprak biçimli, bazı örneklerde tek, bazı örneklerde ise her iki yüzde de genelde baskı tekniğinde paralel düzeltilerin bulunduğu obsidiyen okuçları saptanmıştır (Balcı 2019: 237, 240). Aşıklı Höyük'ün hemen 300 m batısında bulunan ve Çanak Çömleksiz Neolitik dönemin en son evresinde Aşıklı yerleşmesinin uydusu olarak yorumlanan Musular'da oval, baskı düzeltili okucu örnekleri bulunmaktadır. Ancak Musular örneklerinde düzeltilerin alt yüzeyde sadece uç ve sap bölümlerinde görülmesi (Kayacan 2018: 49-50, 58), Avla Dağ örneğini Musular örneklerinden ayırmaktadır.

Avla Dağ'da 2019 yılında gerçekleştirilen yüzey araştırmaları sonucunda az sayıda erken tarihöncesi dönemler içerisinde değerlendirilebilecek çanak çömlek parçaları bulunmuştur. Eldeki örneklerin tümü Avla Dağ 5 buluntu yerinden gelmektedir. Avla Dağ 5 çanak çömleği el yapımı, özlü, bitkisel katkının yoğun, mineral katkının ise daha az kullanıldı̆̆ı, kahverengi astarlı, bazı örneklerde siyah alacalı, dış yüzeyleri açkılı, iç yüzeylerinde ise ince düzeltilerin olduğu bir çanak çömlek grubu olarak tanımlanabilir. Saptanan parçaların büyük bir bölümü gövde parçası niteliğindedir. Az sayıda form veren örnekler arasında açık ağızlı kâse formlarının yanı sıra "S" biçimli pişirme kabına ait olabilecek bir örnek de tespit edilmiştir.

Avla Dağ çanak çömlek buluntuları değerlendirildiğinde, Volkanik Kapadokya bölgesinde karşılaştırılabilecek örnekler Musular'ın geç dönem, çanak çömlekli evresinden, TepecikÇiftlik ve Köşk Höyük yerleşimlerinden bilinmektedir. Musular'ın el yapımı, bitkisel katkılı koyu renkli açkılı mal grubu içerisinde en yaygın formlar düz kenarlı ve "S" profilli derin kâseler olarak tanımlanmıştır. Ayrıca "S" profilli pişirme kapları, büyük düz boyunlu çömlekler, düz kenarlı tabaklar, dışa dönük ağızlı çömlekler, dışa dönük ağızlı kaseler, yuvarlak gövdeli kaseler ve basit düz çömleklerde görülmektedir (Özbaşaran v.d., 2007: 279- 
280). Tepecik-Çiftlik yerleşiminin Çanak Çömlekli Neolitik Dönem'e tarihlendirilen V. ve IV. tabakalarında el yapımı, bitkisel katkılı, özlü, açkılı, alacalı, koyu renkli ve siyah açkılı mal gruplarına ait örnekler açığa çıkartılmıştır. Tutamak ve kulp gibi uzantıların bulunmadığı örneklerde dar ağızlı kapların yanı sıra geniş ağızlı çanaklar da görülmektedir (Bıçakçı v.d. 2007: 242). Köşk Höyük yerleşiminin Çanak Çömlekli Neolitik Dönem buluntuları arasında en yaygın grubu oluşturan el yapımı, gri, kahverengi ve deve tüyü renk tonlarındaki hamurlu, mineral katkılı, özlü, kahverengi ve gri tonlarındaki astarlı ve açkılı örnekleri, Avla Dağ örnekleri ile karşılaştırılabilecek niteliktedir (Öztan 2007: 227).

Yukarıda değerlendirilen buluntular 1şığında, Avla Dağ’da 2019 yılı "yeni dönem" ilk sezon buluntuları üzerinden yapılan ilk gözlemler, Batı Volkanik Kapadokya, Çanak Çömleksiz Neolitik dönemin son evreleri ve Çanak Çömlekli Neolitik dönem yerleşimleri ile var olan benzerlikleri ortaya koymaktadır. Avla Dağ’ın, Çanak Çömleksiz Neolitik öncesi erken tarihöncesi topluluklarının konaklama, özellikle av olmak üzere besin elde etme stratejileri açısından uygun koşulları sağladığı açıktır. Ancak 2019 yılı buluntularının da gösterdiği üzere gün geçtikçe erozyon sebebiyle yok olma tehlikesiyle yüzleşen, muhtemel erken tarihöncesi buluntu yerlerinde daha sistematik ve kapsamlı çalışmaların gerekliliği açıkça görülmektedir. Bu bağlamda Azraq Havzası'nda Garrard ve ekibinin 1975-1988 yılları arasında gerçekleştirdikleri kapsamlı sistematik araştırmalar, iyi bir örnek oluşturmaktadır. Havza kapsamında farklı vadilerde Üst Paleolitik, Epi-Paleolitik ve Neolitik Çăg'a tarihlendirilen birçok buluntu yeri, yüzey araştırmaları, sondaj çalışmaları ve sonrasında gerçekleşen kazı çalışmaları sonucunda açığa çıkartılmıştır. Benzer bir şekilde, tüm tarihöncesi çağları kapsayacak bir yaklaşım benimsenerek, kuzey-güney yönünde 16 km lik bir uzunluğa sahip Avla Dağ üzerindeki birçok mikro alan ve dağın kenarında, kuzeygüney doğrultusunda Ürgüp ilçesi boyunca akan Damsa Çayı ve kollarının oluşturduğu vadiler üzerinde, sistematik yüzey araştırmaları, sondaj çalışmaları ve gerektiğinde kazı çalışmalarının gerçekleştirilmesi, bölge tarihöncesi çağlarındaki 'boşlukları' tamamlaması açısından büyük önem taşımaktadır. Daha küçük ölçekte, Merkezi Volkanik Kapadokya olarak tanımlanan Nevşehir ili ve çevresinin erken tarihöncesi karakterinin anlaşılması sürecinde Avla Dağ’’n anahtar bir araştırma alanı olduğu son derece aşikârdır.

\footnotetext{
Hakem Değerlendirmesi: Dış bağımsız.

Çıkar Çatışması: Yazar çıkar çatışması bildirmemiştir.

Finansal Destek: Yazar bu çalışma için finansal destek almadığını beyan etmiştir.

Peer-review: Externally peer-reviewed.

Conflict of Interest: The author has no conflict of interest to declare.

Grant Support: The author declared that this study has received no financial support.
} 


\section{Kaynakça/References}

Balc1, S. The Obsidian Industry of Pre-Pottery Neolithic levels at Tepecik-Çiftlik, Central Anatolia. L. Astruc, C. McCartney, F. Briois \& V. Kassianidou. Near Eastern Lithic Technologies on the Move Interactions and Contexts in Neolithic Traditions $8^{\text {th }}$ International Conference on PPN Chipped and Ground Stone Industries of the Near East:135-248. Astorm, Nicosia.

Balkan-Atlı, N. \& Cauvin, M. C. (1998). Aksaray, Nevşehir, Niğde İlleri Obsidien Yüzey Araştırması. Araştırma Sonuçları Toplantısı 15(2): 219-232.

Bıçakçı, E. Altınbilek Algül, Ç. Balcı, S. Godon, M. (2007). Tepecik-Çiftlik. M. Özdoğan, N. Başgelen (Ed.), Anadolu'da Uygarlığın Doğuşu ve Avrupa'ya Yayılımı Türkiye'de Neolitik Dönem. Yeni Kazılar, Yeni Bulgular (s. 237-254). Arkeoloji ve Sanat Yayınları, İstanbul.

Byrd, F. B. (1988). Late Pleistocene Settlement Diversity in the Azraq Basin. Paleorient 14(2): 257-264.

Duru, G. (2018). Değiş̧en Zaman, Dönüşen Geçmiş: Volkanik Kapadokya'da Neolitik. Anadolu 44: 157-179.

Garrard, A., Baird, D., Colledge, S., Martin, L. \& Wright, K. (1994). Prehistoric Environment and Settlement in the Azraq Basin: an Interim Report on the 1987 and 1988 Excavation Seasons. Levant 26: 73-109.

Garrard, A., Colledge, S., Montague, R \& Hunt, C. (1998). Environment and Subsistence During the Late Pleistocene and Early Holocene in the Azraq Basin. Paleorient 14(2): 40-49.

Gülçur, S. (1999). Aksaray, Nevşehir, Niğde İlleri 1998 Yüzey Araştırması. Araştırma Sonuçları Toplantısı 17(2): 149-162.

Güngördü, F.V. Başoğlu, O. (2019). Kızılırmak Nehri Kenarında Bir Çanak Çömleksiz Neolitik Dönem Yerleşimi Sofular Höyük. Olba 27: 41-60.

Kayacan, N. (2018). Oval Points and Cattle Hunting Practices in Central Anatolia during the $8^{\text {th }}$ Millenium BC. Adalya 21. 45-61.

Omura, S. (1990). 1989 Yılı Kırşehir, Yozgat, Nevşehir, Aksaray İlleri Sınırları İçinde Yürütülen Yüzey Araştırmaları. Araştırma Sonuçları Toplantısı 8: 69-90.

Özbaşaran, M. (2011). The Neolithic on the Plateau. S. R. Steadman, G. McMahon (eds.), The Oxford Handbook of Ancient Anatolia 10.000-323 B.C.E. (pp. 99-124). Oxford University Press, New York.

Özbaşaran, M. Duru, G. Kayacan, N. Erdoğdu, Buitenhuis, H. (2012). Musular: The 8th Millennium cal. BC Satellite Site of Aşıklı". M. Özdoğan, N. Başgelen, P. Kunihold (eds.), The Neolithic in Turkey, (pp. 135158). Archaeology and Art Publications, İstanbul.

Öztan, A. (2012). Köşk Höyük A Neolithic Settlement in Niğde-Bor Plateau. M. Özdoğan, N. Başgelen, P. Kunihold (eds.), The Neolithic in Turkey, (pp. 31-70). Archaeology and Art Publications, İstanbul.

Richter, T., Maher, L. A., Garrard, A. N., Edinborough, K., Jones, M. D. \& Stock, J. T. (2013). Epipaleolithic Settlement Dynamics in Southwest Asia: New Radiocarbon Evidence from the Azraq Basin. Journal of Quaternary Science 28(5): 467-479.

Roberts, N. (2012). The Climate of Neolithic Anatolia. M. Özdoğan, N. Başgelen, P. Kunihold (eds.), The Neolithic in Turkey, (pp. 67-94). Archaeology and Art Publications, İstanbul.

Şenyurt, S. Y. (1998). Nevşehir İli 1997 Yılı Yüzey Araştırması. Araştırma Sonuçları Toplantısı 16(1): 451466.

(1999). Nevşehir İli 1998 Yılı Yüzey Araştırması. Araştırma Sonuçları Toplantısı 17(2): 365-380.

Todd, I. (1980). The Prehistory of Central Anatolia I The Neolithic Period. Paul Aström Förlag, Göteborg. 
Todd, I. A., Pasquare, G. (1965). The Chipped Stone Industry of Avla Dağ. Anatolian Studies 15, 95-112.

Toprak, V. (1998). Vent distribution and its relation to regional tectonics, Cappadocian Volcanics, Turkey. Journal of Volcanology and Geothermal Research 85, 55-67. 


\section{Şekil, Resim, Tablo ve Grafikler / Figures, Tables and Graphics}

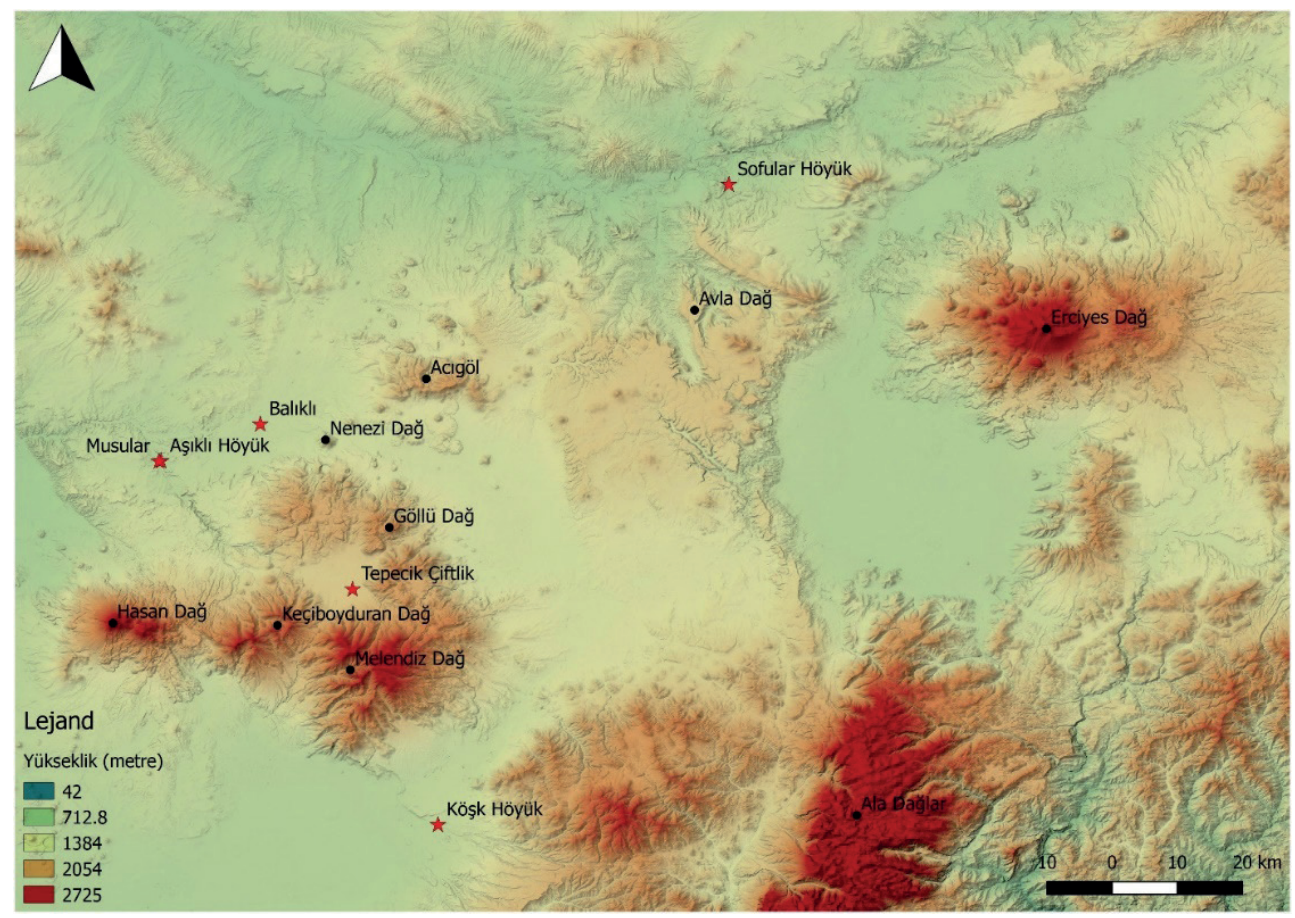

Resim 1. Volkanik Kapadokya
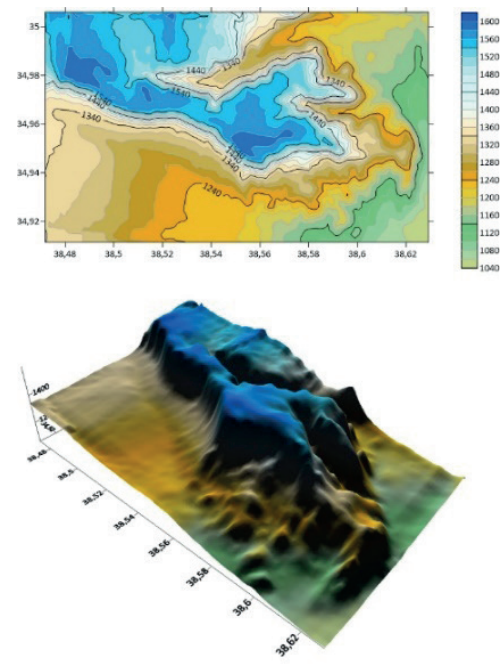

Resim 2. Avla Dağ Topografyası 


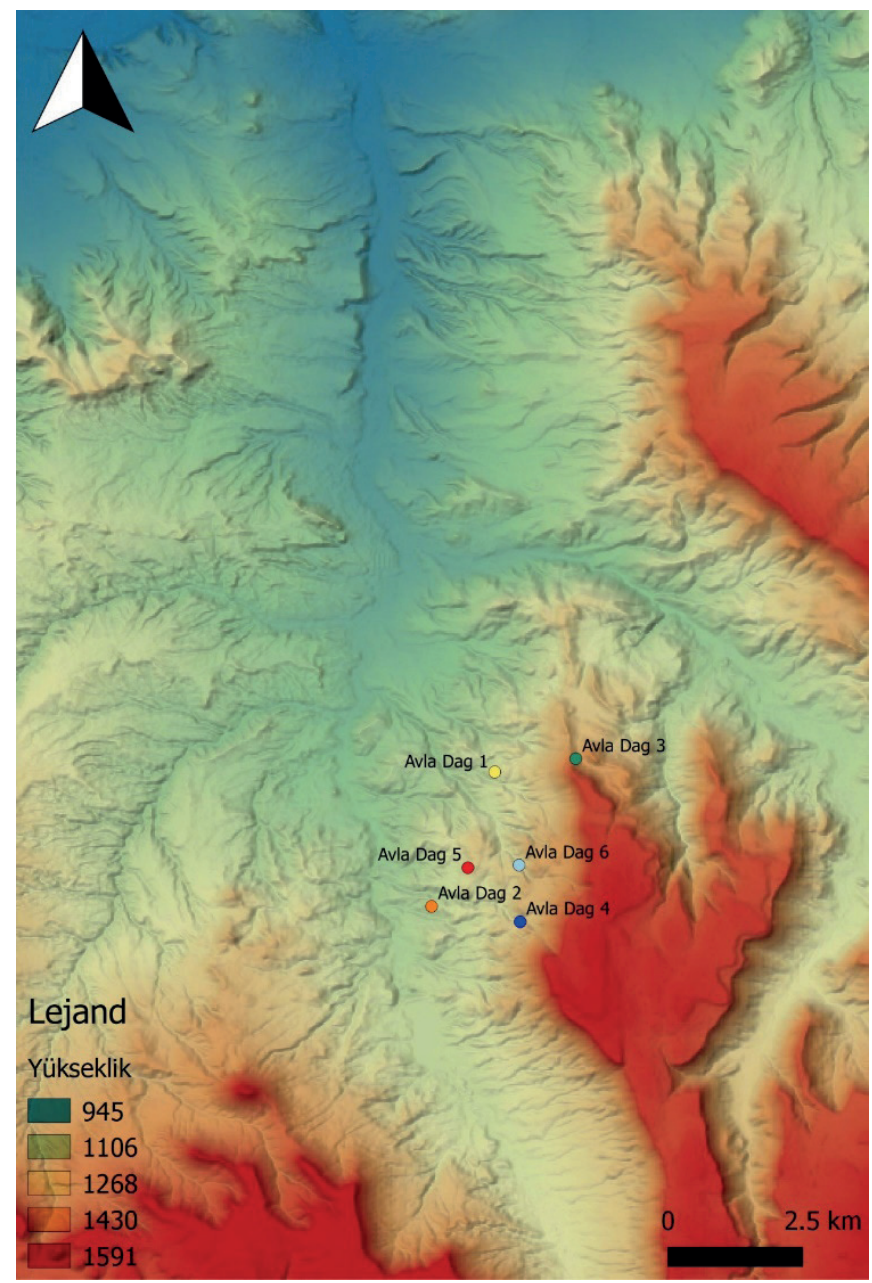

Resim 3. Avla Dağ Üzerindeki Tarihöncesi Buluntu Yerleri 


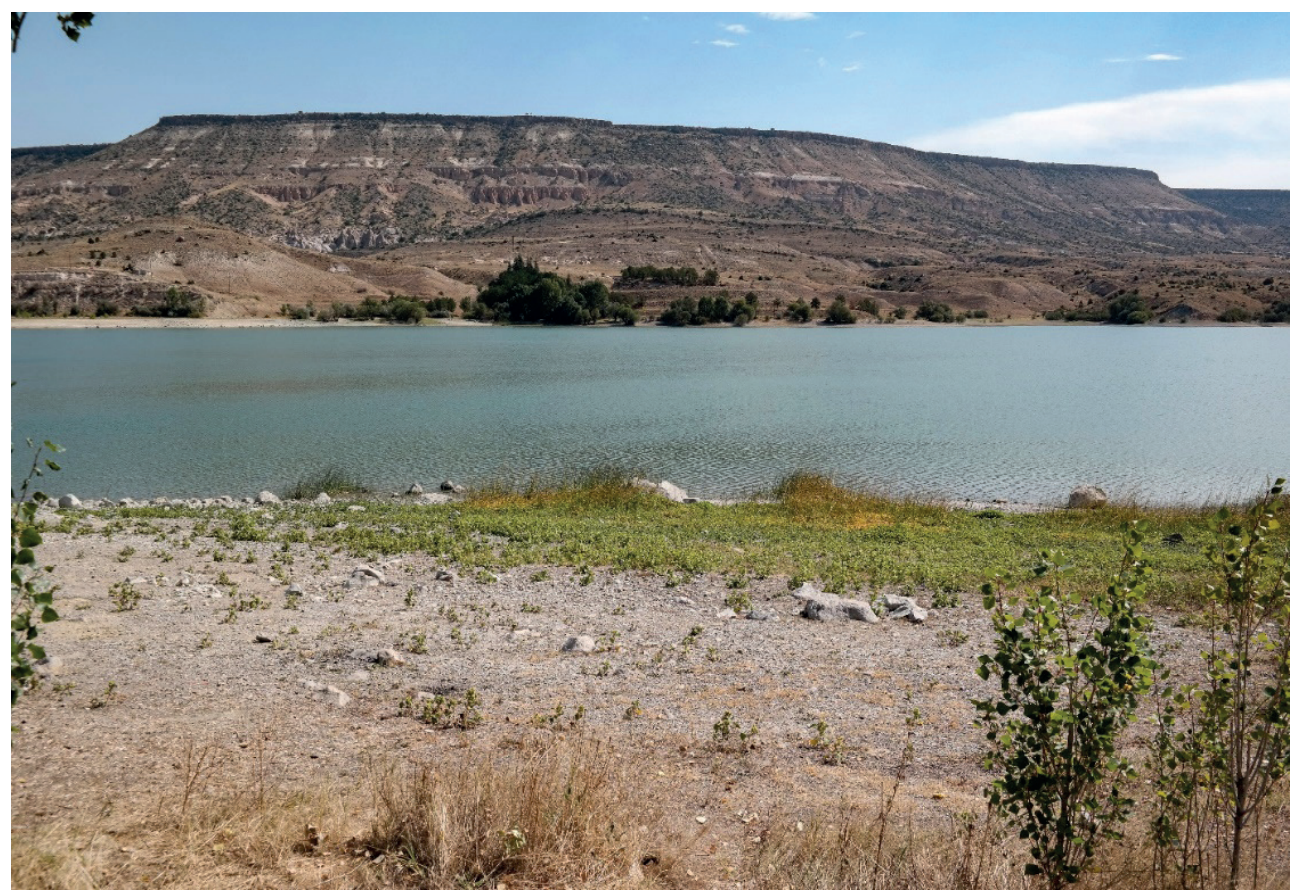

Resim 4. Avla Dağ ve Damsa Baraj Gölü

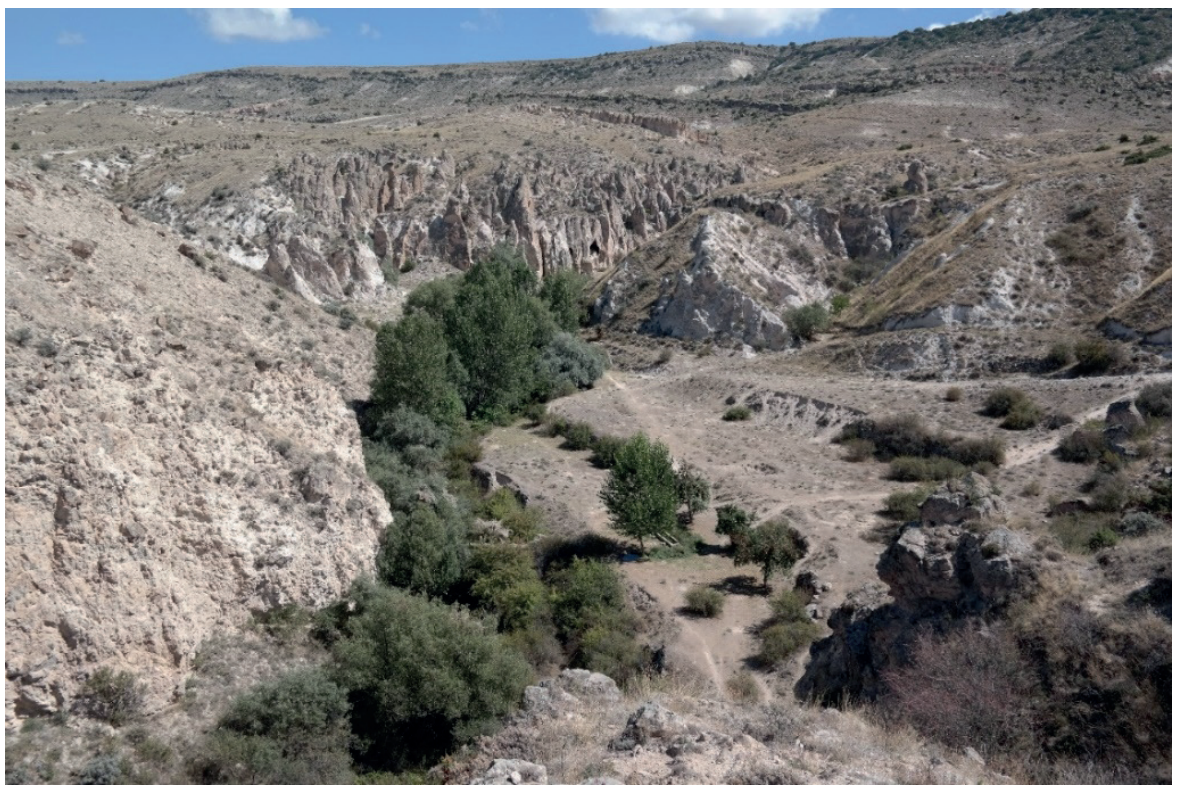

Resim 5. Avla Dağ 2 Buluntu Yeri 

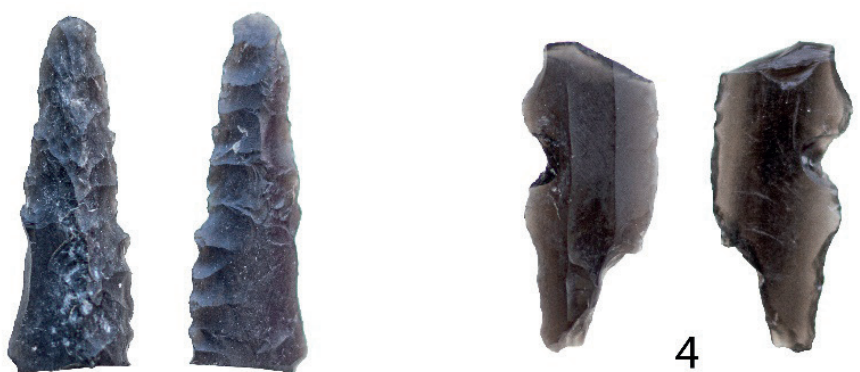

1
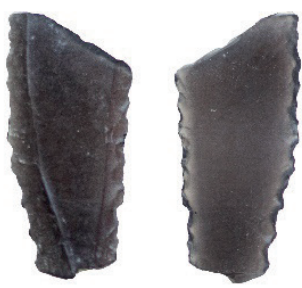

2
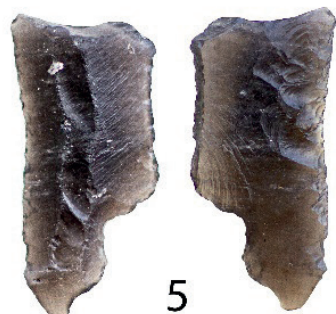

5
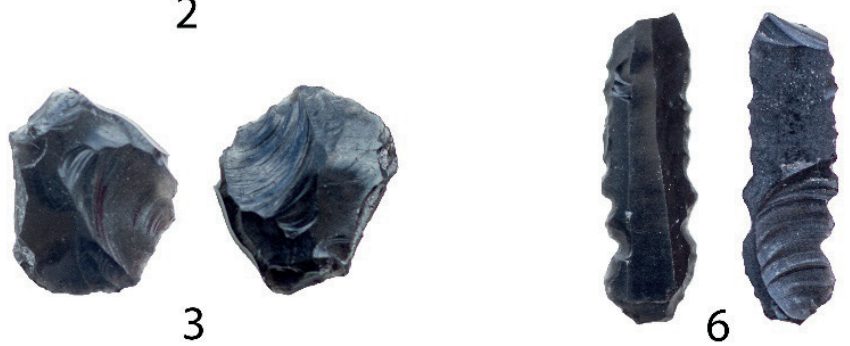

3

6

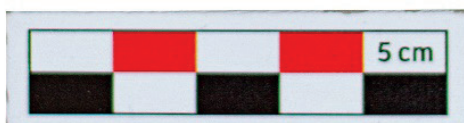

Resim 6. 1. Avla Dağ 4 okucu, 2. Avla Dağ 2 düzeltili dilgi, 3. Avla Dağ 2 kazıyıcı, 4. Avla Dağ 5 çentikli dilgi, 5. Avla Dağ 5 düzeltili dilgi, 6. Avla Dağ 6 düzeltili dilgi 


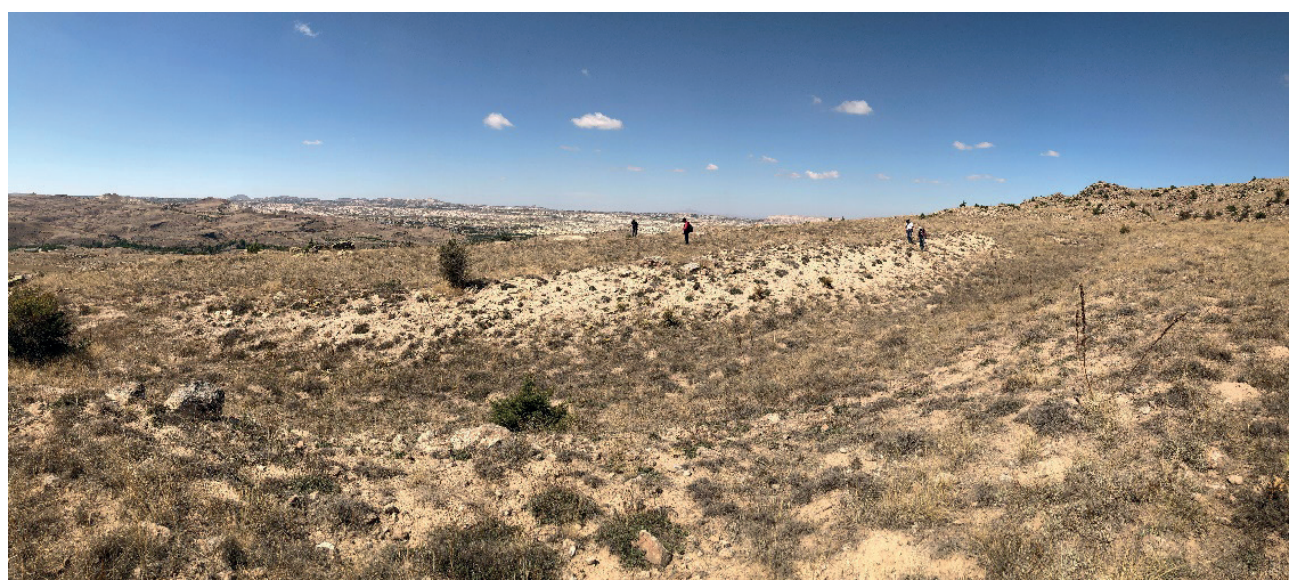

Resim 7. Avla Dağ 5 Buluntu Yeri

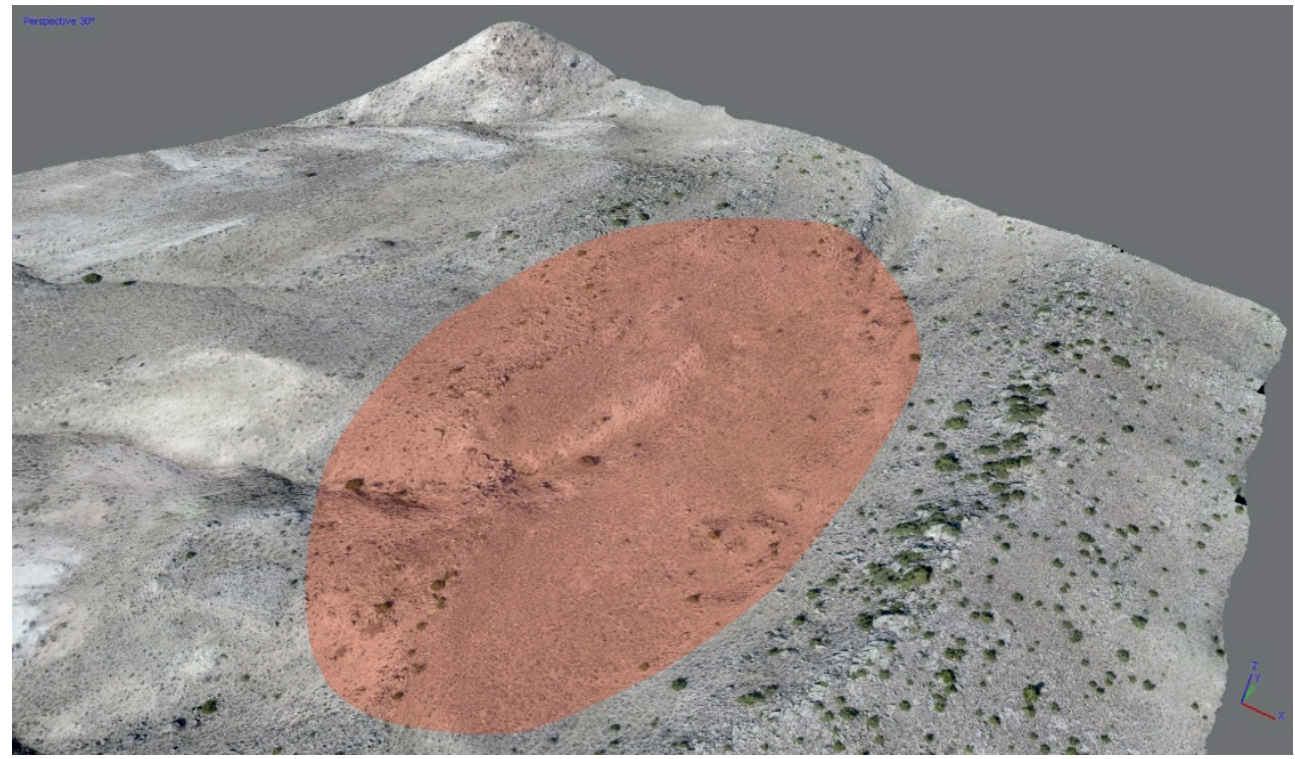

Resim 8. Avla Dağ 5 Buluntu Dağılımı 




Resim 9. Avla Dağ 5, Çanak Çömlek Formları

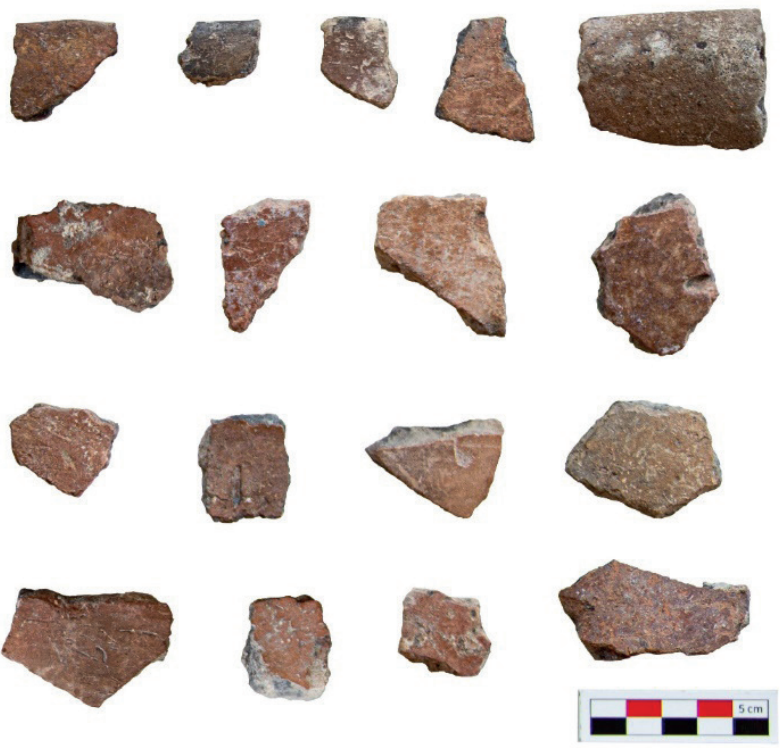

Resim 10. Avla Dağ 5, Çanak Çömlek Örnekleri 




Resim 11. Avla Dağ 2 Buluntu Yerinden Damsa Çayı Vadisi

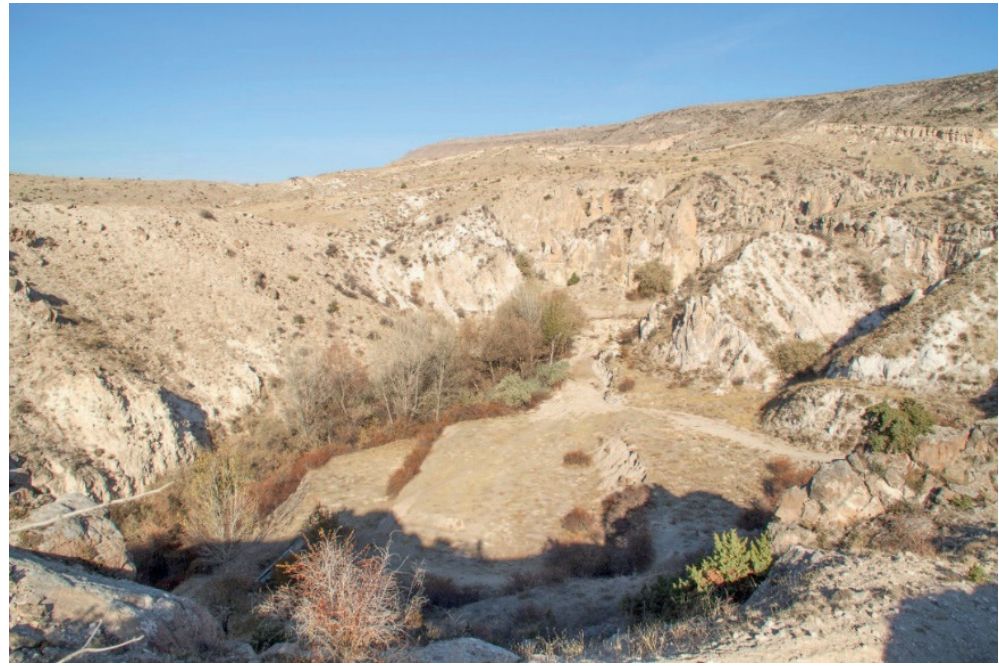

Resim 12. Avla Dağ 2 Mikro Alan 


\begin{tabular}{|c|c|c|c|c|c|c|}
\hline $\begin{array}{l}\text { Buluntu } \\
\text { Yerleri }\end{array}$ & $\begin{array}{c}\text { Dilgi } \\
\text { Parçası }\end{array}$ & $\begin{array}{l}\text { Dilgi Üzeri } \\
\text { Aletler }\end{array}$ & $\begin{array}{l}\text { Yonga } \\
\text { Parçası } \\
\end{array}$ & $\begin{array}{l}\text { Yonga Üzeri } \\
\text { Aletler }\end{array}$ & $\begin{array}{c}\text { Minik } \\
\text { Atık }\end{array}$ & Toplam \\
\hline $\begin{array}{c}\text { Avla Dağ } \\
1\end{array}$ & & & 1 & & 14 & 15 \\
\hline $\begin{array}{c}\text { Avla Dağ } \\
2\end{array}$ & 11 & $\begin{array}{l}1 \text { çentikli, } \\
6 \text { düzeltili, } \\
4 \text { kullanım }\end{array}$ & 16 & $\begin{array}{l}1 \text { kazıyıcı ve } \\
\text { ara parça } \\
1 \text { çakmaktaşı } \\
\text { kazıyıcı } \\
4 \text { düzeltili } \\
4 \text { kullanılmıș, } \\
2 \text { kullanılmış } \\
\text { çakmaktașı }\end{array}$ & 30 & 51 \\
\hline $\begin{array}{l}\text { Avla Dağ } \\
3\end{array}$ & & & 1 & 1 kullanılmıș & 12 & 13 \\
\hline$\underset{4}{\text { Avla Dağ }}$ & 6 & $\begin{array}{l}1 \text { okucu, } \\
5 \\
\text { kullanılmıș }\end{array}$ & 8 & $\begin{array}{l}1 \text { düzeltili, } \\
2 \text { kullanılmıș, } \\
\text { 1çakmaktașı } \\
\text { düzeltili, } \\
1 \text { çakmaktașı } \\
\text { kullanılmıș }\end{array}$ & 22 & 36 \\
\hline $\begin{array}{l}\text { Avla Dağ } \\
5\end{array}$ & 22 & $\begin{array}{l}1 \text { kalem, } \\
1 \text { çentikli } \\
\text { dilgi, } \\
8 \text { düzeltili } \\
\text { dilgi, } \\
11 \\
\text { kullanılmıș } \\
\text { dilgi }\end{array}$ & 20 & $\begin{array}{l}9 \text { kullanılmıș, } \\
2 \text { çakmaktaşı } \\
\text { kullanılmıș }\end{array}$ & 100 & 142 \\
\hline $\begin{array}{c}\text { Avla Dağ } \\
6\end{array}$ & 2 & $\begin{array}{l}2 \text { düzeltili } \\
\text { dilgi }\end{array}$ & 5 & $\begin{array}{l}2 \text { düzeltili, } \\
4 \text { kullanılmıș, } \\
1 \text { çakmaktașı } \\
\text { kullanılmıș }\end{array}$ & 22 & 29 \\
\hline TOPLAM & 35 & & 51 & & 200 & 286 \\
\hline
\end{tabular}

Tablo 1. Avla Dağ Batı Yamacı Lokasyonlarındaki Buluntu Sayısal Değerleri 


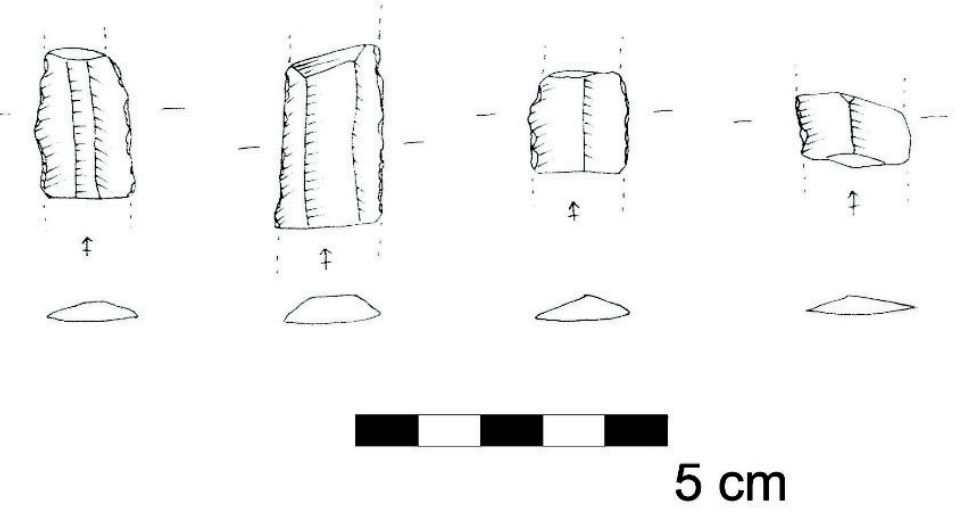

Çizim 1. Avla Dağ 5 Dilgi Parçası Örnekleri 
